This is the version of the working paper published on SSRN: https://papers.ssrn.com/sol3/papers.cfm?abstract id=3198093 Accepted version downloaded from SOAS Research Online: http://eprints.soas.ac.uk/26045

\title{
Climate Vulnerability and the Cost of Debt ${ }^{\text {th }}$
}

\author{
Gerhard Kling ${ }^{\mathrm{a}}$, Yuen C Lo ${ }^{\mathrm{a}}$, Victor Murinde ${ }^{\mathrm{a}}$, and Ulrich Volz ${ }^{\mathrm{a}, \mathrm{b}, \star}$ \\ ${ }^{a}$ SOAS University of London \\ ${ }^{b}$ German Development Institute
}

This version: 18 June 2018

\begin{abstract}
We use indices from the Notre Dame Global Adaptation Initiative to investigate the impact of climate vulnerability on bond yields. Our methodology invokes panel ordinary least squares with robust standard errors and principal component analysis. The latter serves to address the multicollinearity between a set of vulnerability measures. We find that countries with higher exposure to climate vulnerability, such as the member countries of the V20 climate vulnerable forum, exhibit 1.174 percent higher cost of debt on average. This effect is significant after accounting for a set of macroeconomic controls. Specifically, we estimate the incremental debt cost due to higher climate vulnerability, for the V20 countries, to have exceeded USD 62 billion over the last ten years. In other words, for every ten dollars they pay in interest cost, they pay another dollar for being climate vulnerable. We also find that a measure of social readiness, which includes education and infrastructure, has a negative and significant effect on bond yields, implying that social and physical investments can mitigate climate risk related debt costs and help to stabilize the cost of debt for vulnerable countries.
\end{abstract}

JEL Classification: G12, H63, Q51

Keywords: Climate risk, Climate vulnerability, Cost of debt, V20, Climate change

\footnotetext{
This study was conducted as part of research commissioned by the United Nations Environment Programme and the V20 Group, with financial support from the MAVA Foundation. We thank Germanwatch for kindly sharing data of their Climate Risk Index. We are grateful for valuable comments received in the course of this research from Sandy Bisaro, Bob Buhr, Charlie Donovan, Iain Henderson, Seiro Ito, Momoe Makino, Marko Mrsnik, Natalie Pulin, Tatsufumi Yamagata, Brandon Yeh and Simon Zadek. The usual disclaimer applies.
} 
${ }^{*}$ Corresponding author. Department of Economics, SOAS University of London, Thornhaugh Street, London WC1H 0XG, UK. Email: uv1@ soas.ac.uk 


\section{Introduction}

Over the last century, the frequency of natural disasters has increased significantly, as illustrated in Figure 1, with respect to droughts, extreme temperatures, floods, landslides and storm. While only four major hydrometeorological hazards were recorded in the first decade of the 20th century, the number of hazards rose to 3,362 in the first decade of the 21 st century, demonstrating a dramatic increase, also partly due to improvements in record keeping over time. The causes of these hazards are complex, but there is widespread consensus in the scientific community that anthropogenic climate change has led to an increase of temperatures of oceans and the atmosphere, which in turn has contributed to the frequency and severity of extreme weather events. ${ }^{1}$

Figure 1: Number of weather-related catastrophes 1900-2017

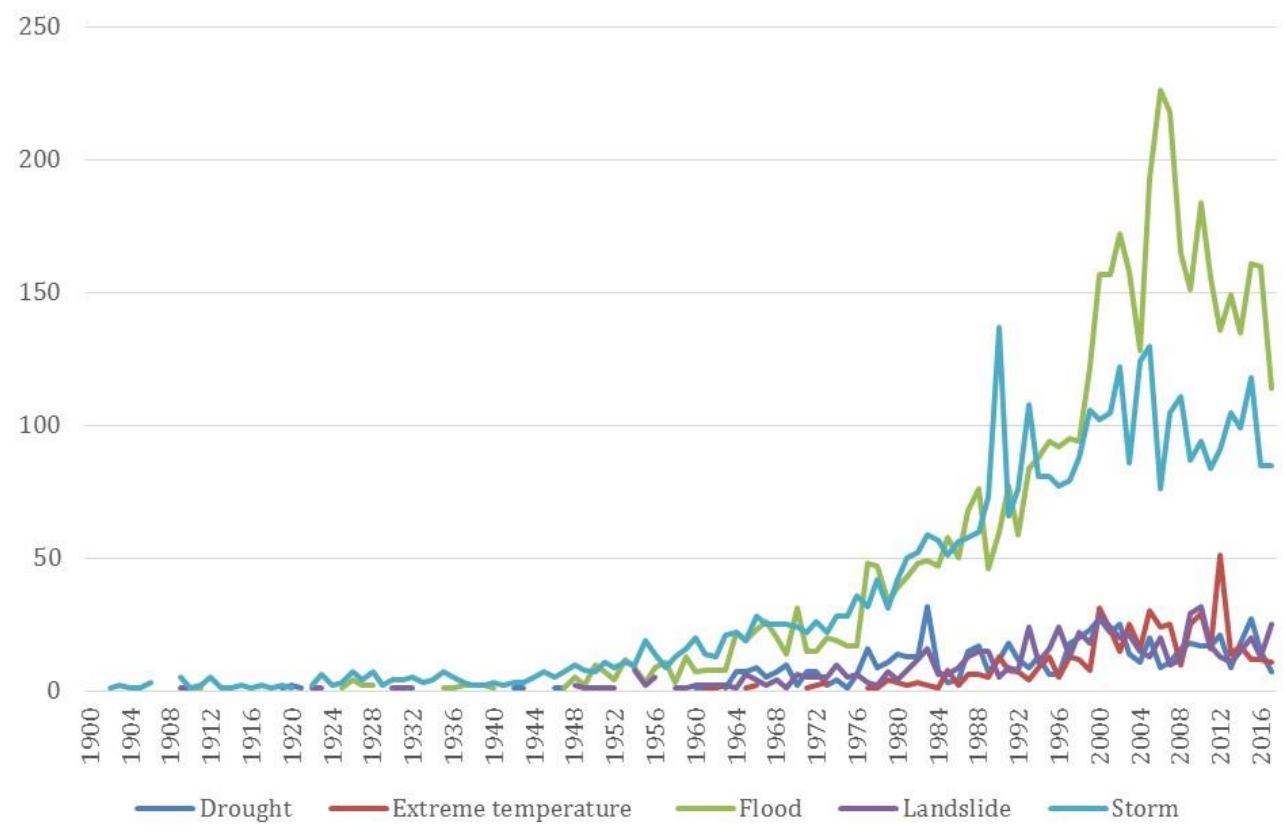

Source: Compiled with data from EM-DAT (2018). Note: The count includes events that meet at least one of the following criteria: (i) 10 or more people reported as dead, (ii) 100 people reported as affected, (iii) a declaration of a state of emergency, or (iv) a call for international assistance.

The natural question that arises from the foregoing discussion is how these weather-related catastrophes translate into economic costs. Existing literature suggests that the occurrence of

\footnotetext{
${ }^{1}$ This argument is consistent with the findings of a new report by the Energy and Climate Intelligence Unit (ECIU, 2017), which shows that climate change is increasing the risk of extreme weather events, including droughts, flooding and heatwaves. See also IPCC (2014) and Fischer and Knutti(2015).
} 
climate-related natural disasters is predicted to rise as temperatures increase, with the prospect of significant negative effects on economic growth (Mei et al. (2015); Mendelsohn et al. (2015); Felbermayr and Groschl (2014); Alano and Lee (2016); Ferreira and Karali (2015)). Indeed, Figure 2 shows the increase in economic losses due to major weather-related events over the last five decades.

Figure 2: Total insured and uninsured losses due to catastrophic weather events

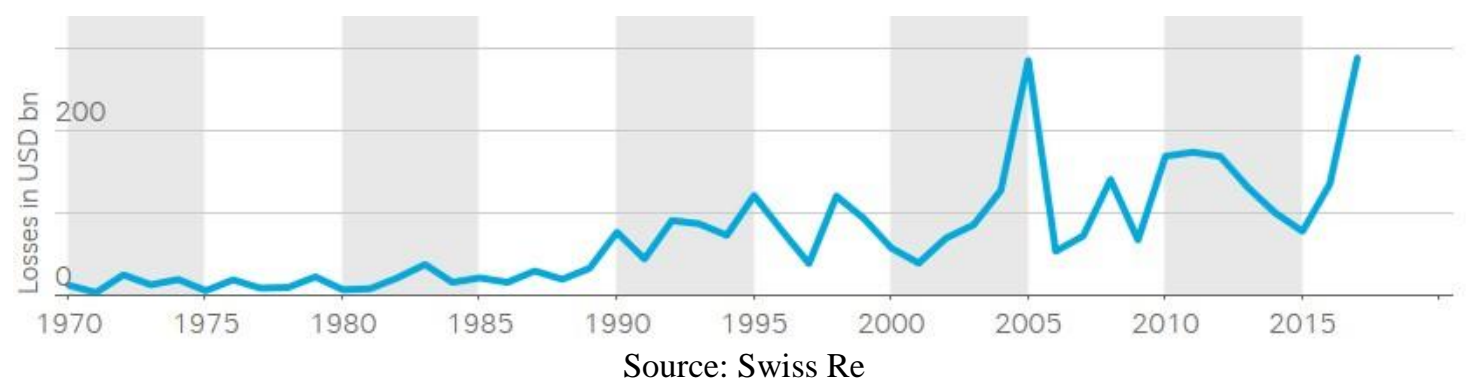

Table 1 presents average annual weather related human fatalities and economic losses 19972016 for a selection of members of the V20 climate vulnerable forum ${ }^{2}$. The five measures are the Climate Risk Indicator (CRI) score published by Germanwatch, deaths, deaths per 100,000 inhabitants, losses in USD million adjusted for purchasing power parity (PPP), and this figure as a percent of PPP GDP. The table as a whole is ranked by CRI score, which is based on the other measures shown. The lower the CRI score, the higher a country's level of exposure and vulnerability to extreme events. Individual statistics are ranked out of 182 countries.

\footnotetext{
${ }^{2}$ The Climate Vulnerable Forcum (CVF) was established in 2009 as an "International partnership of countries highly vulnerable to a warming planet". The original membership of twenty expanded to 49 countries by 2018 .
} 
Table 1: V20 average annual weather related human fatalities and economic losses 1997-2016

\begin{tabular}{|c|c|c|c|c|c|c|c|c|c|}
\hline \multirow[t]{2}{*}{ Country } & \multirow{2}{*}{$\begin{array}{r}\text { CRI } \\
\text { Score }\end{array}$} & \multicolumn{2}{|c|}{ Deaths } & \multicolumn{2}{|c|}{ Deaths 100k } & \multicolumn{2}{|c|}{ Losses in \$mil } & \multicolumn{2}{|c|}{ GDP loss $\%$} \\
\hline & & Avg & Rank & Avg & Rank & Avg & Rank & Avg & Rank \\
\hline Honduras & 12.2 & 302 & 14 & 4.28 & 2 & 561.11 & 31 & 1.97 & 12 \\
\hline Haiti & 13.5 & 280 & 15 & 2.96 & 5 & 418.77 & 36 & 2.73 & 10 \\
\hline Philippines & 20.2 & 860 & 7 & .98 & 18 & $2,893.41$ & 8 & .61 & 35 \\
\hline Bangladesh & 26.5 & 642 & 9 & .44 & 38 & $2,311.07$ & 10 & .68 & 32 \\
\hline Vietnam & 31.8 & 313 & 13 & .37 & 44 & $2,029.80$ & 14 & .55 & 38 \\
\hline Dominican Republic & 34.0 & 211 & 19 & 2.32 & 7 & 243.53 & 53 & .26 & 59 \\
\hline Guatemala & 34.3 & 98 & 30 & .72 & 26 & 402.88 & 40 & .44 & 42 \\
\hline Fiji & 37.8 & 8 & 90 & .97 & 19 & 119.48 & 77 & 1.97 & 11 \\
\hline Madagascar & 37.8 & 79 & 36 & .41 & 39 & 196.41 & 61 & .74 & 26 \\
\hline Cambodia & 38.0 & 54 & 44 & .40 & 41 & 242.69 & 54 & .80 & 24 \\
\hline Grenada & 41.0 & 2 & 132 & 1.93 & 9 & 78.54 & 90 & 7.47 & 3 \\
\hline Afghanistan & 44.2 & 280 & 15 & 1.01 & 16 & 100.29 & 84 & .23 & 67 \\
\hline Nepal & 45.8 & 228 & 18 & .88 & 20 & 108.59 & 81 & .22 & 68 \\
\hline Vanuatu & 55.5 & 2 & 137 & .74 & 24 & 15.85 & 132 & 2.96 & 8 \\
\hline Kenya & 56.0 & 57 & 40 & .16 & 76 & 354.7 & 44 & .36 & 50 \\
\hline Sri Lanka & 59.3 & 49 & 46 & .25 & 61 & 315.62 & 46 & .20 & 71 \\
\hline Colombia & 59.5 & 107 & 27 & .25 & 63 & 609.13 & 30 & .13 & 87 \\
\hline Saint Lucia & 61.0 & 1 & 144 & .67 & 28 & 17.78 & 130 & .98 & 18 \\
\hline Mongolia & 66.8 & 8 & 93 & .29 & 57 & 80.22 & 88 & .32 & 53 \\
\hline Papua New Guinea & 67.7 & 24 & 66 & .39 & 42 & 36.83 & 110 & .20 & 73 \\
\hline Ethiopia & 69.7 & 91 & 31 & .12 & 92 & 180.61 & 65 & .21 & 69 \\
\hline Gambia & 75.5 & 5 & 105 & .32 & 49 & 7.25 & 146 & .33 & 52 \\
\hline Samoa & 76.3 & 0 & 156 & .25 & 62 & 8.60 & 144 & 1 & 17 \\
\hline Yemen & 77.0 & 41 & 52 & .19 & 73 & 113.95 & 78 & .12 & 93 \\
\hline Niger & 77.2 & 15 & 72 & .11 & 97 & 47.02 & 101 & .38 & 48 \\
\hline Malawi & 78.8 & 11 & 76 & .08 & 111 & 61.80 & 95 & .50 & 40 \\
\hline Sudan & 94.0 & 47 & 48 & .13 & 85 & 82.76 & 86 & .06 & 130 \\
\hline Costa Rica & 95.0 & 6 & 96 & .14 & 82 & 50.39 & 98 & .09 & 106 \\
\hline Bhutan & 95.5 & 2 & 137 & .25 & 60 & 5.01 & 154 & .15 & 81 \\
\hline Burkina Faso & 98.0 & 8 & 92 & .05 & 125 & 40.17 & 106 & .20 & 70 \\
\hline Morocco & 98.0 & 17 & 70 & .06 & 124 & 172.14 & 66 & .10 & 102 \\
\hline Ghana & 103.0 & 30 & 62 & .14 & 84 & 32.13 & 114 & .05 & 137 \\
\hline Tanzania & 104.2 & 25 & 65 & .06 & 116 & 61.72 & 96 & .07 & 116 \\
\hline Kiribati & 112.0 & 0 & 174 & 0 & 174 & 10.61 & 140 & 6.6 & 5 \\
\hline Marshall Islands & 112.2 & 0 & 174 & 0 & 174 & 9.02 & 143 & 6.66 & 4 \\
\hline South Sudan & 113.5 & 11 & 80 & .10 & 102 & 16.58 & 131 & .05 & 133 \\
\hline Tuvalu & 114.2 & 0 & 174 & 0 & 174 & 2.63 & 161 & 8.5 & 1 \\
\hline Rwanda & 118.5 & 11 & 78 & .12 & 91 & 3.26 & 157 & .03 & 147 \\
\hline Comoros & 119.3 & 1 & 147 & .16 & 78 & .68 & 171 & .07 & 121 \\
\hline Tunisia & 122.5 & 4 & 115 & .04 & 145 & 64.15 & 94 & .07 & 118 \\
\hline Senegal & 126.7 & 5 & 103 & .04 & 138 & 15.40 & 133 & .06 & 124 \\
\hline Lebanon & 127.0 & 2 & 129 & .06 & 122 & 27.27 & 117 & .05 & 136 \\
\hline Congo, Democratic Rep. of & 131.0 & 33 & 58 & .05 & 130 & 5.74 & 150 & .02 & 159 \\
\hline Barbados & 142.7 & 0 & 173 & .02 & 161 & 3.70 & 155 & .10 & 103 \\
\hline Palau & 167.2 & 0 & 174 & 0 & 174 & .06 & 181 & .02 & 150 \\
\hline Maldives & 169.2 & 0 & 174 & 0 & 174 & .56 & 173 & .01 & 160 \\
\hline Timor-Leste & 171.5 & 0 & 171 & .01 & 170 & .25 & 176 & 0 & 171 \\
\hline
\end{tabular}

Source: Climate Risk Index (CRI), Germanwatch. Note: Ranked out of 182. Losses in USD purchasing power parity 
According to the rankings, the countries in the table are not always ranked the highest: Clearly, many climate vulnerable countries sit outside the V20 forum. For example, using the average GDP loss percentage, the highest in ranking amongst the V20 are Tuvalu (1), Grenada (3), Marshall Islands (4), Kiribati (5), Vanuatu (8), Haiti (10), Fiji (11), Honduras (12) - seven of which are small island states. When the countries are ranked by losses in USD million, only the Philippines (8), Bangladesh (10) and Vietnam (14) are ranked in the highest 20; the rankings of the rest of the sample countries are below this. Larger more developed countries are subject to higher nominal dollar losses.

As discussed in the literature review below, and highlighted by Gerling (2017), although research into the long term economic costs of both climate change and disasters is abundant, the body of knowledge is altogether inconclusive. In addition, work on the fiscal impacts of climate change is less well developed. The most critical missing link, however, is the dearth of research that investigates the effect of climate vulnerability on the cost of sovereign debt. This is an important gap in knowledge mainly because the cost at which governments can access finance does not only affect the public budget and the government's ability to invest in climate mitigation and adaptation, but it also constrains possible investments in areas such as infrastructure, education and public health, and has ramifications for investments undertaken by the private sector. In fact, there is likely to be a wide range of spillover effects. Moreover, while existing empirical work shows that the most critical variable affecting the Weighted Average Cost of Capital - which is a crucial variable for investment appraisal - is the sovereign risk score assigned to each country (Ameli et al., 2017), there is no evidence on the relationship between climate impacts, risks and vulnerability, and the cost of sovereign debt. For clarity, we define climate impacts as the physical manifestations of man-man climate change, for example increased frequency of floods and droughts. Climate vulnerability combines both sensitivity to climate change, as well as capacity to absorb and adapt to climate change. Climate risks includes the negative financial outcomes attributable to anthropogenic climate change. The later is multidimensional, spanning transition 
costs as society switches to electric vehicles, to physical risks such as loss of fisheries as ocean temperatures change.

This paper seeks to address the existing gap in knowledge by investigating a subset of climate risk, the impact of climate vulnerability on sovereign bond yields. We use a panel ordinary least squares (POLS) methodology to estimate a linear model that attempts to explain sovereign bond yields using a set of control variables, climate vulnerability and social preparedness measures. We also invoke principal component analysis in order to address the inherent multicollinearity between a set of climate vulnerability measures. We find a positive and statistically significant coefficient on climate vulnerability, and a negative and statistically significant coefficient on social preparedness. The climate vulnerability variable includes structural weaknesses such as dependency on imported energy and food that clearly implies higher sensitivity to climate change. The social preparedness variable includes measures such as education and Internet access that are effectively non-GDP measures of development and infrastructure.

In addition, the empirical results of our base model generate an estimate of $12.4 \%$ as the average linear debt cost prediction for a V20 country, based on control variables such as debt to GDP and government revenue and expenditure. Our results show that climate vulnerability, as measured by the Notre-Dame Global Adaptation Initiative (ND-GAIN) sub-indices for climate sensitivity and capacity, increases debt costs by 1.17 percentage points. This is the average partial impact of climate vulnerability on V20 countries' cost of debt. This increase can be partially offset by investments in social and physical infrastructure, which according to our empirical estimates reduces the cost of debt by an average of $0.67 \%$. The coefficient on this preparedness index suggests that investments (that do not necessarily depend on GDP) can mitigate higher debt costs arising from higher climate vulnerability. Multiplying this incremental cost (adjusted for average V20 climate vulnerability) and historic external public and private debt for the V20 group of climate vulnerable countries implies a USD 62 billion higher cost of debt over the last ten years. We consider this a lower bound based on direct effects, for a subset of climate vulnerabilities, for a subset of countries with poor access to finance. 
The rest of the paper is structured as follows. Section 2 reviews the literature. Section 3 addresses the data underlying this study and is complimented by a table of the variables in Appendix A. Section 4 explains the methodology underlying our empirical model. Section 5 provides some descriptive analysis while the empirical results are presented in Section 6. Section 7 offers some comments on our climate vulnerability cost estimate. We provide a variety of robustness checks in Section 8. Section 9 discusses selection bias that arises from being dependent on bond yield data reported by Bloomberg, and the relationship between this bias and our climate vulnerability measure. We close with a short conclusion.

\section{Brief literature review}

Existing literature summarizes the science behind climate change, links it to physical risks and connects this to the functioning of the global economy (see, for example, Farid et al. (2016)). As illustrated in Figure 2, costs from catastrophic weather events are rising. However, the research relating to the economic growth effects of climate change is not so clear-cut. For example, Cavallo et al. (2013) use a combined case study framework, with synthetic controls, and finds that only large disasters impact growth and even the observed impact may be caused by subsequent political changes rather than the disasters themselves. However, Fomby et al. (2013) find that while the results for droughts and floods are statistically significant, only the results for floods show a positive cumulative impact on economic growth. These findings are consistent with an earlier finding by Raddatz (2007) that climate shocks can only explain a small portion of the output variance of low income countries.

Notwithstanding the above evidence, a selection of papers find a negative impact on economic growth. Loayza et al. (2012) attempt to reconcile contradictory studies by delving deeper into individual economic sectors. Cabezon et al. (2015) use a panel VAR model and finds an 0.7\% reduction in trend growth in a group of Pacific islands due to natural disasters. Alano and Lee (2016) estimate empirically the link between typhoon wind speed and economic losses in Asia.

It is with Gerling (2017) that the literature begins to examine differences in loss dimensions. 
The paper uses a panel-VARX specification with an exogenous disaster dummy and four endogenous variables (real GDP per capita growth, primary balance, tax revenue and expenditures). The author notes that material damages, people affected and the number of casualties are poorly correlated. Each dimension triggers different macro-fiscal responses. The studies summarized above struggle to answer whether the initial direct costs are compounded by reconstruction efforts crowding out productive capital expenditures, or completely offset by accelerated Schumpeterian creative destruction. Gerling also points out that most studies focus on the economic impact, only a few examine the fiscal performance.

The significance of fiscal effects are difficult to confirm. Acevedo (2014)'s VAR model finds that public debt increases following major floods, but this only applies to a subset of the storms they study. Cabezon et al. (2015) uses a panel VAR model to detect a worsening of the fiscal balance (solely in the first year) for small pacific island states. Melecky and Raddatz (2011) also uses a panel VAR framework and discover that on average budget deficits increase only after climatic disasters, but for lower-middle income countries the increase in deficits occurs across all types of events. Their vector of endogenous variables includes the log of real government expenditures, GDP per capita in constant 2000 US dollars, the inflation rate and government revenues. The authors build on Melecky and Raddatz (2014) and find that countries with more sophisticated debt markets suffer smaller real consequences from disasters but that their deficits expand further.

In Glass et al. (2015), Standard and Poor's points out that it is rare for the debt of a country to be downgraded due to a natural disaster. Grenada in 2004, following Hurricane Ivan, is given as one of these exceptional situations. However they point out that a major reason for this is that often the countries most affected do not have a sovereign rating at the date of the catastrophe. Glass et al. (2015, page 4) conclude: 'We believe that sovereigns most vulnerable to natural hazards are likely to be small island states with next to no geographical diversification and a narrow economic base'

The reviewed literature suggests inconclusive evidence that risky weather events harms economic growth, but becomes clearer with respect to the substantial associated costs. While there is also considerable research in the linked fields of insurance, catastrophe bonds and risk mitigation, 
there is also relatively little literature on whether risky weather events may trigger a change in ratings, for example a downgrade by rating agencies. There is scant evidence on the mediator / moderator variable that is cost of debt, as it relates to climate risk and vulnerability, and climate related catastrophes, and how climate vulnerability may be increasing this cost of debt capital. An example is the PhD thesis by Ozcan (2005), which follows an event study methodology. We look to add to the literature an empirical analysis, focused on climate vulnerability and the cost of debt. The hypothesis that we test is does climate vulnerability and social preparedness impact cost of debt? The set of controls chosen cover the majority of those mentioned in the priorliterature.

\section{Data and variables}

The data for YIELD is based on weekly bond yield data collected from Bloomberg. This includes marketable debt for 17 of the V20 group of climate vulnerable countries: Bangladesh, Burkina Faso, Colombia, Costa Rica, Dominican Republic, Ghana, Guatemala, Kenya, Lebanon, Mongolia, Morocco, Philippines, Rwanda, Senegal, Tanzania, Tunisia, and Vietnam. In addition, we use annual multilateral bond yield observations, recorded by the International Monetary Fund (IMF), on eight V20 countries: Ethiopia, Fiji, Honduras, Malawi, Maldives, Nepal, Papua New Guinea and Vanuatu. This IMF debt category is typically at concessional rates contracted via multilateral or bilateral agreements. Estimation of our model is conducted with and without an IMF dummy in order to isolate this effect. We have also assembled data on 21 countries outside the V20: the 7 countries of the G7 Group of advanced economies, and for 14 other middle to less developed countries. The majority of the bond yield data is for 10 year benchmark rates, however this is not the case for all of them. For example, the Burkina Faso data is the average yield from 5 year government bond auctions, whereas for Guatemala it is a benchmark weekly yield on 20 year government debt. We select benchmark debt time series according to the longest period of time available. Local currency benchmarks are preferred over foreign currency bonds. Multilateral debt is usually denominated in USD or IMF special drawing rights. A list of all countries included in the emprical model can be seen in Appendix C. 
Our control data is sourced primarily from the IMF. The per capita income variable (PCY) refers to GDP per capita at purchasing power parity in US dollars. DEBT is gross government debt to GDP. REV is government revenue to GDP. EXP is government expenditure to GDP. PBA is the government's primary balance to GDP. CPI is inflation as measured by end of period consumer price indices. The FDI variable comes from the United Nations Conference on Trade and Development (UNCTAD), and is normalized relative to GDP.

The three main dummies of the model are: (i) V20, representing the climate vulnerable countries of the V20 Group; (ii) G7, reflecting the seven major economies of the G7; and (iii) IMF, representing V20 bond yield observations linked to multilateral debt, and recorded by the IMF.

The climate vulnerability and readiness data is from the Notre Dame Global Adaptation Index (ND-GAIN), which brings together 74 variables to form 45 core indicators to measure sensitivity and readiness of over 180 countries. As alluded to by the word adaptation, the headline index is a measure of how countries are dealing with the risks they face - the highest ranked country in 2017 was Norway. Changes to a country's headline index is a respected measure of that country's efforts at addressing climate risk. We focus in on three sub-indices that reflect micro level measures of vulnerability and preparedness: (i) NDS is a sensitivity index that incorporates factors such as food import dependency, slum population and dependency on imported energy; (ii) NDC is a capacity index based on components such as child malnutrition, access to reliable drinking water and electricity access; (iii) NDSR is a social readiness index based on measures such as social inequality, ICT infrastructure, and education. ND-GAIN constructs its sub-indices by scaling each variable to a 0 to 1 score relative to a benchmark level. What we exclude is as relevant as what we include. We have chosen to leave out the ND-GAIN exposure component as it is based on projections of climate change rather than actual data, and the ND-GAIN economic readiness index which is based on the World Bank's Doing Business Index. A table of all the variables can be found in Appendix A.

Additionally, we check our results with the Climate Risks Indicator (CRI) provided by Germanwatch; and agricultural value added as a proportion of GDP, as reported by the World Bank 
(not shown). We also considered other indices such as the World Risk Index for our analysis. Unfortunately many of these indices are available only for relatively short time spans. A further issue is that purely physical climate indices are poorly suited to our methodology, as they show little variation over time, which means they cannot explain observed variation in our dependent variable. Using actual weather events (as captured, for instance, in the EM-DAT Emergency Events Database) is also problematic because it is the losses that count. Put simply, weather events in areas with little economic activity cannot be expected to have much impact on the economy and hence bond yields. Including country level data on economic losses due to climate-related weather events in our econometric analysis would have been desirable, but was not possible due to data limitations. This may be a direction for future research.

For the estimation of historic incremental debt costs, due to climate vulnerability, we use total external debt stocks from the World Bank Development Indicator Databank, with the series code DT.DOD.DECT.CD (downloaded 30 March 2018). It is defined as debt owed to non-residents repayable in currency, goods, or services. Total external debt is the sum of public, publicly guaranteed, and private non-guaranteed long-term debt, use of IMF credit, and short-term debt. Shortterm debt includes all debt having an original maturity of one year or less and interest in arrears on long-term debt. This data series is in current U.S. dollars.

\section{Methodology}

The weekly bond observations are converted into annual figures in order to perform a panel ordinary least squares analysis (POLS):

$$
\mathbf{y}_{t}=\alpha+\beta \mathbf{x}_{t}+\gamma \mathbf{z}_{t}+\mathrm{E}_{t}
$$

Where $\beta$ is a $k \times 1$ coefficient vector, $\mathbf{x}_{t}$ is a $k \times 1$ vector of climate-related variables, $\gamma$ is a $p \times 1$ coefficient vector, $\mathbf{z}_{t}$ is a $p \times 1$ vector of controls. Although $\alpha$ is a $k \times 1$ vector, all the intercepts are assumed to be identical within this framework. This feature is discussed further 
below. The dependent variable $y_{t}$ are country bond yields. Subscript $t$ is the year. We conduct multiple regressions to test the significance of the set of climate variables and controls.

A fixed effects model where each country has its own intercept was also considered:

$$
\mathbf{y}_{i t}=\theta_{i} \theta_{i} D_{i}+\beta^{\mathbf{T}} \mathbf{x}_{i t}+\gamma^{\mathbf{T}} \mathbf{z}_{i t}+\mathrm{E}_{i t}
$$

Unfortunately, because some countries had very few usable annual datapoints, such a framework risked over-specifying the model. In addition, other variables mimic country effects due to their low variability over time.

Our model is a linear regression model and hence all the standard assumptions apply (OLS assumptions of linearity, spherical error terms, exogeneity). A linear prediction of base cost of debt

for the average V20 country, climate vulnerability and social preparedness is estimated by taking conditional expected values of the dependent variable. Mechanically this multiplies the coefficients estimated by the model with the variables themselves. We can then observe the mean, median and standard deviation values for members of the V20 group of climate vulnerable countries. The base effect is the predicted cost of debt minus the partial climate vulnerability and social preparedness effects.

Essentially, the average of the V20 sub-sample of explanatory variables is used to derive estimates of climate vulnerability cost. Further, we assume that parameters are constant, i.e. the partial impact of climate vulnerability on cost of debt does not change over time. Specifically, our model only identifies the direct effect of climate vulnerability on cost of debt; indirect effects through macroeconomic variables are not modeled. For example, we do not capture interventions such as IMF support, which is assumed to be exogenous, i.e. independent from climate vulnerability.

\section{Descriptive analysis}

Table 2 shows descriptive statistics for all countries. Table 3 focuses on the V20 countries. Government bond yields are higher in V20 countries on average, and there is a considerable gap in 
GDP per capita, government revenues and expenditures. The mean of the CPI indicator is clearly highly skewed by extreme observations for both groups.

Table 2: Descriptive statistics: All countries

\begin{tabular}{lcccccc}
\hline & $\mathrm{N}$ & Mean & St Dev & P25 & P50 & P75 \\
\hline YIELD & 473 & 7.468 & 6.028 & 3.760 & 5.820 & 9.540 \\
NDS & 3762 & 0.403 & 0.098 & 0.332 & 0.396 & 0.477 \\
NDC & 3960 & 0.513 & 0.170 & 0.390 & 0.493 & 0.653 \\
NDSR & 4048 & 0.308 & 0.161 & 0.194 & 0.257 & 0.376 \\
PCY & 6351 & 8350 & 13659 & 798 & 2589 & 9505 \\
DEBT & 4104 & 57.256 & 49.904 & 28.400 & 46.250 & 71.250 \\
REV & 4292 & 29.236 & 13.463 & 18.577 & 26.981 & 38.076 \\
EXP & 4268 & 31.734 & 14.058 & 20.985 & 29.676 & 40.628 \\
PBA & 4065 & -0.011 & 7.031 & -2.327 & -0.214 & 2.092 \\
CPI & 5892 & 35.623 & 359.970 & 2.000 & 4.800 & 10.500 \\
FDI & 6619 & 16.311 & 260.635 & 0.444 & 1.682 & 4.527 \\
\hline
\end{tabular}

We recommend caution when attempting to interpret these averages as many of these time series are unbalanced e.g. the bond yield data for France covers 1998 to 2018 while the bond yield data for Senegal is only for 2013 and 2014. We note that the measures of climate vulnerability NDS and NDC are higher for the V20 countries, and the measure of social readiness NDSR is lower. From this preliminary description of the data set, the question arises whether the observed difference in cost of capital can be explained by the chosen set of explanatory variables.

Table 3: Descriptive statistics: V20 countries

\begin{tabular}{lcccccc}
\hline & $\mathrm{N}$ & Mean & St Dev & P25 & P50 & P75 \\
\hline YIELD & 174 & 10.307 & 6.586 & 6.200 & 7.975 & 12.660 \\
NDS & 880 & 0.451 & 0.085 & 0.396 & 0.464 & 0.503 \\
NDC & 924 & 0.629 & 0.124 & 0.530 & 0.635 & 0.730 \\
NDSR & 990 & 0.230 & 0.084 & 0.172 & 0.214 & 0.274 \\
PCY & 1563 & 1931 & 2617 & 421 & 958 & 2286 \\
DEBT & 930 & 57.864 & 43.087 & 33.200 & 45.700 & 69.800 \\
REV & 988 & 21.594 & 13.090 & 13.788 & 18.801 & 25.129 \\
EXP & 985 & 25.002 & 14.051 & 17.015 & 22.198 & 28.746 \\
PBA & 916 & -1.329 & 4.427 & -2.881 & -1.061 & 0.886 \\
CPI & 1459 & 28.914 & 316.806 & 2.900 & 6.300 & 11.800 \\
FDI & 1564 & 2.732 & 3.977 & 0.341 & 1.325 & 3.894 \\
\hline
\end{tabular}


The data on debt yields is not normally distributed, exhibiting positive skewness due to the large positive outliers shown in Figure 3. Accordingly, a log transformation is applied to ensure a symmetric distribution of the dependent variable

Figure 3: Kernel density of nominal yields

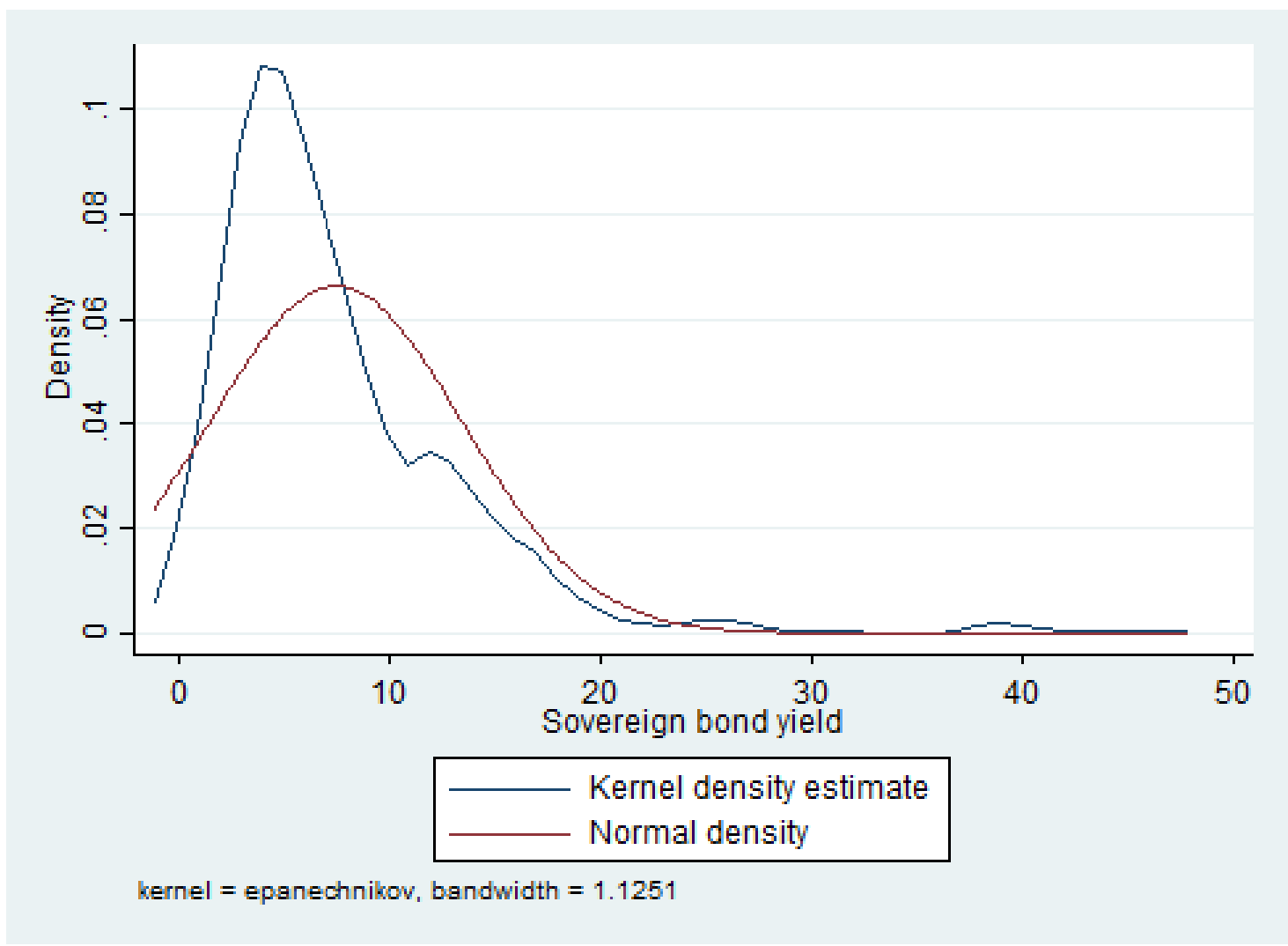




\section{Multivariate analysis}

Table 4 shows our initial regression model using POLS with robust standard errors. We present nominal yields in the descriptive statistics above, however as noted the multivariate analysis specifies the natural logarithm of our annual bond yield observations as the dependent variable.

Table 4: Determinants of log yields

\begin{tabular}{lllll}
\hline & \multicolumn{1}{c}{$[\mathrm{A}]$} & \multicolumn{1}{c}{$[\mathrm{B}]$} & \multicolumn{1}{c}{$[\mathrm{C}]$} & \multicolumn{1}{c}{$[\mathrm{D}]$} \\
\hline NDS & $1.106^{* * *}$ & $1.222^{* * *}$ & $1.068^{* * *}$ & $0.679^{*}$ \\
NDC & 0.527 & $0.778^{*}$ & 0.399 & 0.176 \\
NDSR & $-1.605^{* * *}$ & $-1.727^{* * *}$ & $-1.624^{* * *}$ & $-2.495^{* * *}$ \\
PCY & $0.000^{* *}$ & $0.000^{* * *}$ & $0.000^{* *}$ & -0.000 \\
DEBT & $-0.010^{* * *}$ & $-0.009^{* * *}$ & $-0.010^{* * *}$ & $-0.010^{* * *}$ \\
REV & $-0.185^{* * *}$ & $-0.172^{* * *}$ & $-0.179^{* * *}$ & $-0.168^{* * *}$ \\
EXP & $0.182^{* * *}$ & $0.172^{* * *}$ & $0.177^{* * *}$ & $0.159^{* * *}$ \\
PBA & $0.149^{* * *}$ & $0.140^{* * *}$ & $0.144^{* * *}$ & $0.112^{* * *}$ \\
CPI & $0.006^{* * *}$ & $0.006^{* * *}$ & $0.006^{* * *}$ & $0.006^{* *}$ \\
FDI & $0.024^{*}$ & $0.026^{*}$ & 0.017 & 0.018 \\
IMF & & $-0.231^{*}$ & $-0.264^{* *}$ & $-0.294^{* * *}$ \\
V20 & & & $0.203^{* * *}$ & $0.168^{* *}$ \\
G7 & & & & $0.974^{* * *}$ \\
\hline aic & 363.596 & 359.889 & 351.807 & 324.058 \\
bic & 406.435 & 406.622 & 402.434 & 378.580 \\
Adjusted $R^{2}$ & 0.738 & 0.741 & 0.748 & 0.767 \\
$N$ & 363 & 363 & 363 & 363 \\
\hline All models refer to POLS using the Huber-White sandwich estimator. \\
${ }^{*} p<0.05,{ }^{* *} p<0.01,{ }^{* * *} p<0.001$ & &
\end{tabular}

The explanatory power is satisfactory with an adjusted R-squared of approximately $75 \%$. We observe a positive coefficient on our key climate sensitivity measure NDS, implying the possibility that higher sensitivity may be correlated with higher bond yields. This index includes measures such as food import dependency, slum population and dependency on imported energy. The coefficient on NDC is positive but generally not statistically significant. The negative and significant result on our NDSR measure of social readiness confirms the importance of investments in ICT infrastructure and education in reducing the cost of debt and mitigating the risks of climate change. The use of a per capita income PCY variable controls for the inherent correlation of many of these measures with gross domestic product. 
We note the high degree of correlation between NDSR, NDS and NDC, leading to high variance inflation factors in excess of the critical value of 10. The matrix of correlation coefficients is presented in Appendix B. We observe that although the acronyms are ND-Sensitivity, ND-Capacity and ND-Social Readiness, sensitivity and capacity are in fact positively correlated at 0.611 , while social readiness is negatively correlated with sensitivity at -0.515 , and with capacity at -0.886 . We suggest that although capacity includes measures such as dam capacity, its effect is to map out the relative paucity of suchcapacity.

To address the multicollinearity inherent in our climate vulnerability indicators, we conduct a principal component analysis (PCA) of the NDS and NDC variables. Note that NDSR is a preparedness indicator. This statistical methodology allows us to reduce the the number of variables by formulating them as two uncorrelated linear combinations of the variables, the first of which contains the majority of the variance.

Figure 4: Scree plot of Principal Component Analysis eigenvalues

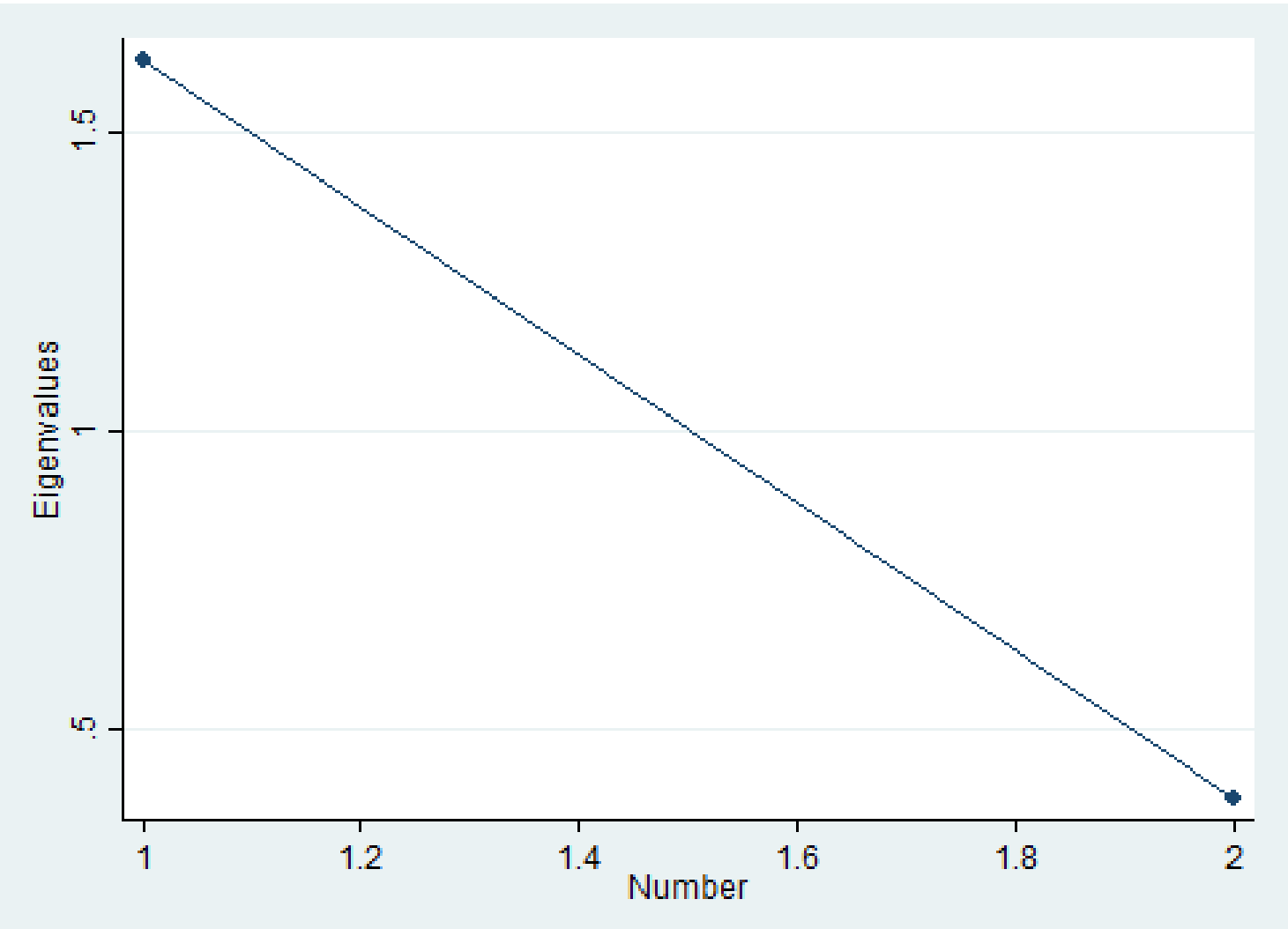

We determine the number of components appropriate to our model by using a scree plot as 
shown in Figure 4. Eigenvalues are below one, after one component is considered, suggesting that a single component is sufficient.

Table 5: Determinants of yields based on PCA

\begin{tabular}{|c|c|c|c|c|}
\hline & {$[\mathrm{A}]$} & [B] & {$[\mathrm{C}]$} & [D] \\
\hline SCORE & $0.146^{\star \star \star}$ & $0.176^{\star \star \star}$ & $0.135^{\star \star \star}$ & $0.081^{*}$ \\
\hline NDSR & $-1.557^{\star \star \star}$ & $-1.764^{\star \star \star *}$ & $-1.541^{\star \star \star}$ & $-2.410^{\star \star \star}$ \\
\hline PCY & $0.000^{\star *}$ & $0.000^{* * *}$ & $0.000^{* *}$ & -0.000 \\
\hline DEBT & $-0.010^{\star * *}$ & $-0.010^{\star \star \star}$ & $-0.010^{\star \star \star}$ & $-0.010^{\star \star \star}$ \\
\hline REV & $-0.185^{\star \star \star}$ & $-0.171^{\star \star * *}$ & $-0.178^{* * *}$ & $-0.168^{* * \star}$ \\
\hline EXP & $0.182^{* \star *}$ & $0.172^{* \star *}$ & $0.178^{\star \star \star}$ & $0.160^{\star \star \star}$ \\
\hline PBA & $0.150^{\star \star \star}$ & $0.140^{\star \star \star}$ & $0.145^{\star \star \star}$ & $0.112^{\star \star \star}$ \\
\hline CPI & $0.006^{* * *}$ & $0.006^{* * *}$ & $0.006^{* * *}$ & $0.006^{* *}$ \\
\hline FDI & $0.024^{*}$ & $0.026^{*}$ & 0.018 & 0.019 \\
\hline IMF & & $-0.227^{\star *}$ & $-0.271^{* *}$ & $-0.300^{\star * \star}$ \\
\hline V20 & & & $0.197^{\star \star \star}$ & $0.162^{\star \star}$ \\
\hline G7 & & & & $0.974^{\star * *}$ \\
\hline aic & 361.649 & 357.925 & 350.024 & 322.297 \\
\hline bic & 400.593 & 400.763 & 396.757 & 372.925 \\
\hline Adjusted $R^{2}$ & 0.739 & 0.742 & 0.748 & 0.767 \\
\hline$N$ & 363 & 363 & 363 & 363 \\
\hline
\end{tabular}

All models refer to POLS using the Huber-White sandwich estimator. ${ }^{*} p<0.05,{ }^{* *} p<0.01,{ }^{* * *} p<0.001$

Based on the PCA model, we define our own climate vulnerability index (SCORE) based on the ND-GAIN sensitivity and capacity indices. Table 5 demonstrates that the SCORE variable has a positive and significant impact on yield - particularly after controlling for multilateral IMF debt yields, which are based on concessionary rates. We note that although country dummies are statistically significant, they are also subject to strong selection biases related to access to financial markets. In summary, our findings suggest that climate vulnerability has a positive impact on cost of debt, while developmental indicators reflected in the NDSR have a negative impact on the cost of debt.

\section{Estimated additional debt cost due to climate vulnerability}

Our estimate is based on statistics for external public, publicly guaranteed and private debt from the World Bank Development Indicator Databank, for 40 members of the V20 group of 
climate vulnerable countries. The number of countries is determined by data availability. This figure totaled USD 768 billion in 2016 and USD 5.4 trillion over the ten year period 2007 to 2016. Estimated climate vulnerability impacts for V20 countries are shown in Table 6. The V20 countries included in the empirical model reflect $86 \%$ of the external debt reported by the World Bank for the wider V20 group.

Table 6: V20 incremental debt yield estimates

\begin{tabular}{lccc}
\hline & mean & $\mathrm{p} 50$ & $\mathrm{sd}$ \\
\hline BASE & 12.420 & 12.270 & 3.357 \\
CLIMATE & 1.174 & 1.213 & 0.198 \\
PREPAREDNESS & -0.674 & -0.686 & 0.092 \\
\hline
\end{tabular}

Multiplying external debt by our estimated climate vulnerability impact of 1.17\% (adjusted for $\log$ yields and the V20 average climate vulnerability SCORE) generates an estimate of ten year historical cost exceeding USD 62 billion. This estimate of direct effects connects with many related issues that are beyond the scope of this paper. External debt for this sample of V20 countries rose by over $5 \%$ in 2016 . The percentage of equity to capital required typically increases with perceived risk (e.g. sovereign debt rating), which would be more of an issue in V20 countries as (1) equity is generally scarce in less developed, largely domestic financial systems and (2) any increase in equity can dramatically increase the weighted average cost of capital. Both the higher debt cost and increased equity requirements would logically decrease the universe of positive net present value investment opportunities relative to required hurdle rates. Similarly higher hurdle rates and worse sovereign credit ratings may decrease the supply of international private sector capital.

To the extent that cost of debt limits investment in key sectors, it would then change the profile of such investment. This might potentially reflect a bias towards conventional investments over sustainable or climate resilient investments with higher initial capex requirements.

\section{Robustness checks}

In Table 7 we present three checks of robustness. Column 1 is the empirical result from above. Column 2 highlights how some controls have negatively impacted the number of observations, 
specifically with respect to a number of V20 countries. In selecting our empirical model we have prioritized the number of observations. Model [C] in column 3 introduces a risk free rate RFR control based on US 10 year Treasury yields. The number of observations declines as the United States is no longer included in the model as observations of the dependent variable.

Table 7: Robustness checks

\begin{tabular}{|c|c|c|c|c|}
\hline & {$[\mathrm{A}]$} & [B] & {$[\mathrm{C}]$} & [D] \\
\hline SCORE & $0.176^{* * *}$ & $0.133^{\star \star \star}$ & $0.168^{* * *}$ & $0.217^{\star * \star}$ \\
\hline NDSR & $-1.764^{* * *}$ & $-2.006^{* * *}$ & $-1.891^{* * *}$ & $-1.569^{* * *}$ \\
\hline PCY & $0.000^{\star * *}$ & 0.000 & $0.000^{\star * *}$ & $0.000^{\star * *}$ \\
\hline DEBT & $-0.010^{\star \star *}$ & $-0.005^{\star * *}$ & $-0.010^{* \star *}$ & $-0.010^{\star \star *}$ \\
\hline REV & $-0.171^{\star * *}$ & & $-0.159^{* \star *}$ & $-0.171^{\star * *}$ \\
\hline EXP & $0.172^{* * *}$ & & $0.160^{* * *}$ & $0.172^{* * *}$ \\
\hline PBA & $0.140^{* * *}$ & & $0.115^{\star * *}$ & $0.140^{\star * *}$ \\
\hline CPI & $0.006^{* * *}$ & $0.008^{* * *}$ & $0.006^{* * *}$ & $0.007^{* *}$ \\
\hline FDI & $0.026^{*}$ & $0.026^{*}$ & $0.022^{*}$ & $0.029^{*}$ \\
\hline $\mathrm{IMF}$ & $-0.227^{* *}$ & $-0.483^{* * *}$ & $-0.258^{* *}$ & \\
\hline RFR & & & $0.331^{* * *}$ & \\
\hline MAT & & & & -0.264 \\
\hline$M A T^{2}$ & & & & 0.019 \\
\hline aic & 357.925 & 510.050 & 326.171 & 335.156 \\
\hline bic & 400.763 & 541.799 & 372.362 & 380.997 \\
\hline Adjusted R2 & 0.742 & 0.620 & 0.758 & 0.753 \\
\hline$N$ & 363 & 391 & 347 & 337 \\
\hline
\end{tabular}

In column 4 we address the differences in maturity by introducing a polynomial of the maturity. Because the cost of debt data is limited for many countries of our sample group, and many choose to issue bonds primarily at maturities other than ten years, we have chosen the most comprehensive time series available for each. Maturities vary from 5 years, 8 years, 9 years, 10 years and 20 years, with 10 years being the most common. This is a non-optimal way to address differences in maturity as it estimates a yield curve assuming that there is a universal yield curve which is unlikely to exist. Bond yield observations on IMF concessionary debt is not included in model [D] as their maturity is undefined in the data.

These robustness checks confirm the original result of a positive and statistically significant 
coefficient on the climate vulnerability measure SCORE and a negative and statistically significant coefficient on the social readiness measure NDSR, at the $99.9 \%$ significance level.

\section{Sample selection bias}

Thus far, our empirical model focuses on countries for which yield data is observable and available via the data provider Bloomberg. This implies that our regression analysis operates under the condition that countries can issue sovereign bonds (and that debt issues are of sufficient size and liquidity to warrant recording by Bloomberg). This is not the case for all V20 countries. Our POLS model is valid as a second-stage model. Hence we determine the conditional expected value of bond yields influenced by climate vulnerability and other factors under the condition that countries have access to capital markets. The first-stage problem becomes understanding the underlying factors that enable countries to issue bonds. In this selection stage, climate vulnerability and other control variables might play another role. Accordingly, there is a possibility that climate vulnerability reduces a country's access to capital markets, in addition to the direct yield effect analyzed earlier.

\subsection{Logistic model of exclusion from capital markets}

Table 8 shows our results based on a logistic regression, where access to capital markets, proxied as having observable sovereign bond yields, is the dependent variable. Specification [S1] focuses on climate vulnerability exclusively, indicating a pseudo R-squared of 0.163 , relativelyhigh for a single explanatory variable. Model [S2] includes all controls used in the first-stage model and a V20 country dummy, showing a general group-specific disadvantage in accessing capital markets. Both specifications reveal that climate vulnerability, yet again, affects V20 countries negatively. The likelihood of being excluded (coded as one) increases with climate vulnerability throughout all specifications. Moreover, investments in social and physical infrastructure (NDSR) can reduce the likelihood of exclusion. This effect is even stronger for V20 countries as shown in model [S3] as the interaction term is highly significant; in fact, the sign of the variable NDSR 
Table 8: Predicting exclusion from capital markets

\begin{tabular}{lllll}
\hline & {$[\mathrm{S} 1]$} & \multicolumn{1}{c}{$[\mathrm{S} 2]$} & \multicolumn{1}{c}{$[\mathrm{S} 3]$} & \multicolumn{1}{c}{$[\mathrm{S} 4]$} \\
\hline EXC & & & & \\
SCORE & $0.869^{* * *}$ & $0.909^{* * *}$ & $0.928^{* * *}$ & $0.299^{* *}$ \\
NDSR & & $-6.687^{*}$ & $123.226^{* *}$ & $-7.735^{* * *}$ \\
PCY & & $0.000^{*}$ & $0.000^{* *}$ & $-0.000^{* * *}$ \\
DEBT & & $0.032^{* * *}$ & $0.033^{* * *}$ & $0.015^{* * *}$ \\
REV & & 0.132 & 0.140 & $0.217^{* * *}$ \\
EXP & -0.100 & -0.109 & $-0.153^{* *}$ \\
PBA & & -0.008 & -0.017 & -0.069 \\
CPI & -0.000 & -0.001 & 0.007 \\
FDI & $0.108^{*}$ & $0.108^{*}$ & $0.129^{* * *}$ \\
V20 & $15.537^{* *}$ & $103.708^{* *}$ & \\
NDSRxV20 & & & $-130.176^{* *}$ & \\
\hline aic & 1322.908 & 512.686 & 513.032 & 918.635 \\
bic & 1333.197 & 564.380 & 569.426 & 967.802 \\
Pseudo $R^{2}$ & 0.163 & 0.561 & 0.562 & 0.318 \\
$N$ & 1267 & 812 & 812 & 1009 \\
\hline All models refer to POLS using the Huber-White sandwich estimator. \\
${ }^{*} p<0.05,{ }^{* *} p<0.01,{ }^{* * *} p<0.001$ & &
\end{tabular}

switches from negative to positive. As a check of robustness, model [S4] excludes dummies and the interaction term, confirming prior findings for all countries.

We use specification [S3], with the highest pseudo R-squared of about 56\%, as our reference model. To illustrate the impact of climate vulnerability, it would be more appropriate to use model [S4]. Figure 5 plots the predicted probability of facing difficulties in raising capital from debt markets, differentiating the sample countries between membership in the V20 group, and members of the G7 or G24. A clear pattern emerges in that V20 countries, after controlling for all other factors, exhibit a high risk of exclusion, and climate vulnerability makes access to capital markets even more of a challenge. Each dot represents a country-year, and the estimated probability that the specific country-year is not associated with a cost of debt observation within our empirical model. 
Figure 5: Predicted probability for exclusion

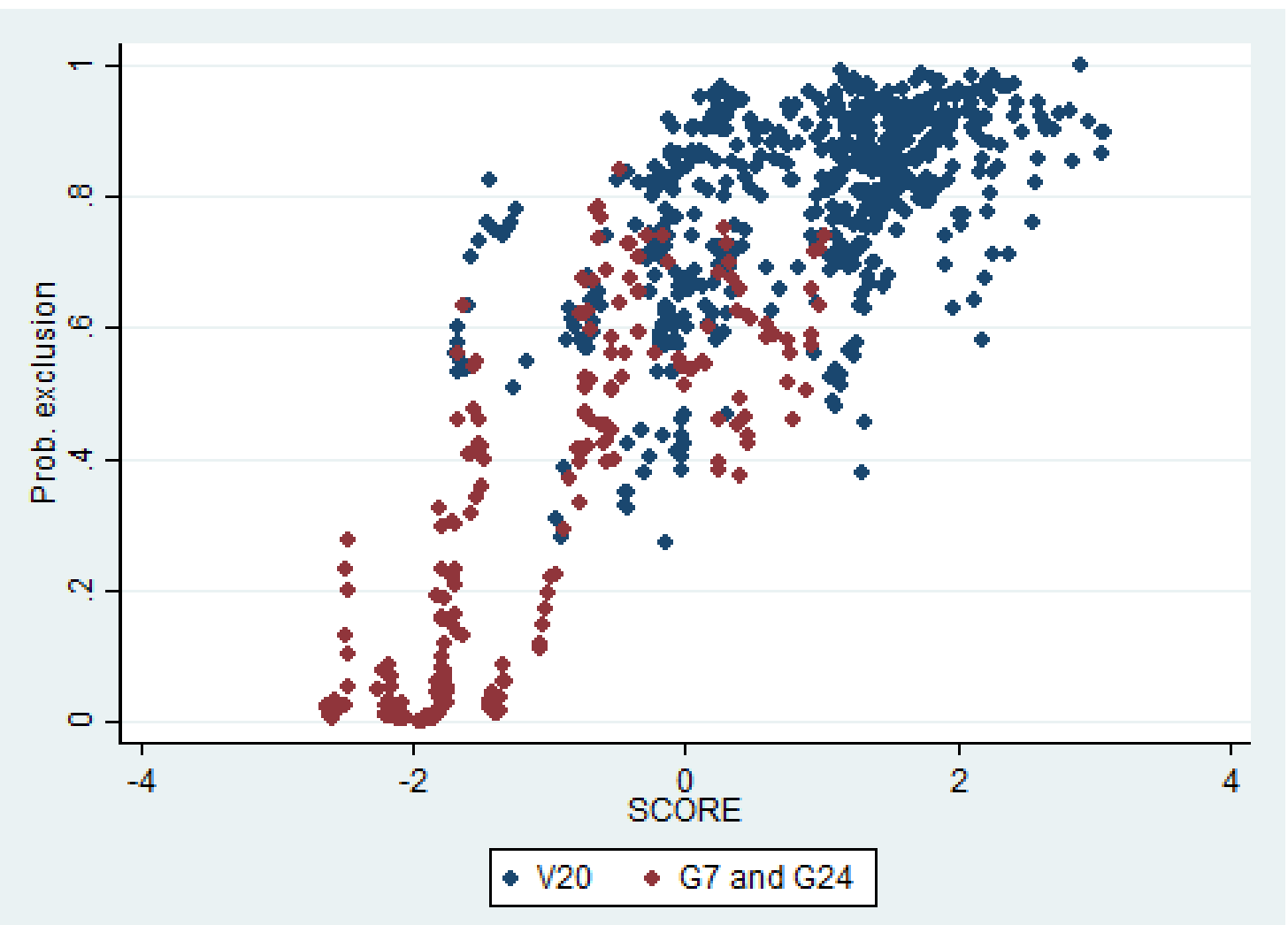

\section{Conclusion}

This paper fills an important gap in knowledge by investigating the impact of climate vulnerability on sovereign bond yields. It provides early evidence that measures of climate vulnerability have a positive impact on the cost of sovereign debt. This statistically significant result highlights one channel of financial cost that the V20 climate-vulnerable countries bear because of their higher exposure to vulnerabilities such as higher dependency on natural capital or greater water dependency ratio. We estimate the debt cost due to higher climate vulnerability to have exceeded USD 62 billion over the last ten years. Our logistic model indicates a negative correlation between climate vulnerability and ability to raise capital in size. All these results are after controlling for conventional macroeconomic and fiscal drivers of the cost of debt. Our results also draw attention to how the adverse impact of climate vulnerability can be mitigated by investment in ICT infrastructure, education and health for those countries which are most at need. 
Future directions of this work could examine the interrelation between rating changes, bond yields and climate vulnerability using a qualitative short panel vector auto-regression model. This could reveal whether ratings drive markets or vice versa. Secondly, it would be interesting to explore direct and indirect effects of climate vulnerability using a structural equation model. This could help to determine whether climate vulnerability acts directly or indirectly by affecting macroeconomic variables or both.

\section{Bibliography}

Acevedo, S. (2014), Debt, growth and natural disasters: A Carribean trilogy, Working paper 14/125, International Monetary Fund.

Alano, E. and Lee, M. (2016), Natural disaster shocks and macroeconomic growth in asia: evidence for typhoons and droughts, Working paper 503, Asian Development Bank.

Ameli, N., Biancardi, A., Drummond, P., Leonidas, P., Grubb, M., Vrontisi, Z., Kostas, F., Panagiotis, F. and Mandel, A. (2017), 'Stylised models of relative rates of return, technology co-benefit / spillover effects for key sectors', mimeo, London: University College London .

Cabezon, E., Hunter, L., Tumbarello, P., Washimi, K. and Wu, Y. (2015), Enhancing macroeconomic resilience to natural disasters and climate change in the small states of the pacific, Working paper 15/125, International Monetary Fund.

Cavallo, E., Galiani, S., Noy, I. and Pantano, J. (2013), 'Catastrophic natural disasters and economic growth', The Review of Economics and Statistics 95(5), 1549-1561.

ECIU (2017), Heavy weather: Tracking the fingerprints of climate change, two years after the Paris summit, Technical report, Energy and Climate Intelligence Unit.

Farid, M., Keen, M., Papaioannou, M., Parry, I., Pattilo, C. and Ter-Martirosyan, A. (2016), After Paris: fiscal, macroeconomic, and financial implications of climate change, Technical report, International Monetary Fund. 
Felbermayr, G. and Groschl, J. (2014), 'Naturally negative: the growth effects of natural disasters', Journal of Development Economics 111, 92-106.

Ferreira, S. and Karali, B. (2015), 'Do earthquakes shake stock markets?', PLoS ONE 7(10).

Fischer, E. M. and Knutti, R. (2015), 'Anthropogenic contribution to global occurrence of heavyprecipitation and high-temperature extremes', Nature Climate Change 5, 560-564.

Fomby, T., Ikeda, Y. and Loayza, N. V. (2013), 'The growth aftermath of natural disasters', Journal of Applied Econometrics 28(3), 412-434.

Gerling, K. (2017), The macro-fiscal aftermath of weather-related disasters: Do loss dimensions matter?, Working paper 17/235, International Monetary Fund.

Glass, B., Kraemer, M., Mrsnik, M. and Petrov, A. (2015), Storm alert: Natural disasters can damage sovereign creditworthiness, Technical report, Standard and Poor's.

IPCC (2014), Climate change 2014: Synthesis report. contribution of working groups i, ii and iii to the fifth assessment panel on climate change, Technical report, Intergovernmental Panel on Climate Change.

Loayza, N. V., Olaberr'1a, E., Rigolini, J. and Christiaensen, L. (2012), 'Natural disasters and growth: Going beyond the averages', World Development 40(7), 1317 - 1336.

Mei, W., Xie, S.-P., Primeau, F., McWilliams, J. C. and Pasquero, C. (2015), 'Northwestern Pacific typhoon intensity controlled by changes in ocean temperatures', Science Advances 1(4).

Melecky, M. and Raddatz, C. (2011), How do Governments respond after catastrophes?, Working paper 5564, World Bank.

Melecky, M. and Raddatz, C. (2014), 'Fiscal responses after catastrophes and the enabling role of financial development', The World Bank Economic Review 29(1), 129-149. 
Mendelsohn, R., Kerry, E., Chonabayashi, S. and Bakkensen, L. (2015), 'The impact of climate change on global tropical cyclone damage', Nature Climate Change 2, 205-209.

Ozcan, B. (2005), Market convergence, catastrophe risk and sovereign borrowing: An empirical analysis for emerging market countries, PhD thesis, Fletcher School of Law and Diplomacy.

Raddatz, C. (2007), 'Are external shocks responsible for the instability of output in low-income countries?', Journal of Developmental Economics 84, 155-187. 


\section{Appendix A. Table of variables}

\begin{tabular}{|c|c|c|}
\hline Variable & Source & Definition \\
\hline YIELD & Bloomberg & $\begin{array}{l}\text { Up to weekly Sovereign Bond yield observations collected on } 46 \text { countries to estimate an } \\
\text { annual bond yield. For liquid markets this would be } 52 \text { observations of generic benchmark } \\
\text { yields as calculated by Bloomberg. For other markets this might reflect the average yield } \\
\text { at a debt auction. IMF bonds are discussed below. Clean or dirty (including accrued } \\
\text { coupons) pricing is used based on market convention. Local currency bonds are chosen } \\
\text { over USD versions. }\end{array}$ \\
\hline NDS & $\begin{array}{l}\text { Notre-Dame } \\
\text { Global } \\
\text { Adaptation } \\
\text { Initiative }\end{array}$ & $\begin{array}{l}\text { The ND-GAIN Sensitivity index consists of } 12 \text { measures including: Food import de- } \\
\text { pendency, rural population, fresh water withdrawal rate, water dependency ratio, slum } \\
\text { population, dependency on external resource for health services, dependency on natural } \\
\text { capital, ecological footprint, urban concentration, age dependency ratio, dependency on } \\
\text { imported energy, and population living under } 5 \mathrm{~m} \text { above sea level. Statistics are rebased } \\
\text { to } 0 \text { to } 1 \text {, relative to a selected benchmark level. }\end{array}$ \\
\hline NDC & $\begin{array}{l}\text { Notre-Dame } \\
\text { Global } \\
\text { Adaptation } \\
\text { Initiative }\end{array}$ & $\begin{array}{l}\text { The ND-GAIN capacity index consists of } 12 \text { measures including: agriculture capacity } \\
\text { (fertilizer, irrigation, pesticide, tractor use), child malnutrition, access to reliable drink- } \\
\text { ing water, dam capacity, medical staff, access to improved sanitation, protected biomes, } \\
\text { engagement in international environmental conventions, quality of trade and transport re- } \\
\text { lated infrastructure, paved roads, electricity access and disaster preparedness. }\end{array}$ \\
\hline
\end{tabular}




\begin{tabular}{|c|c|c|}
\hline Variable & Source & Definition \\
\hline SCORE & $\begin{array}{l}\text { PCA of NDS } \\
\text { and NDC }\end{array}$ & $\begin{array}{l}\text { Principal Component Analysis (PCA) is a mathematical tool that generates orthogonal } \\
\text { linear combinations, in this case of our NDS and NDC indices, with the majority of the } \\
\text { variance contained in the first vector generated. }\end{array}$ \\
\hline NDSR & $\begin{array}{l}\text { Notre-Dame } \\
\text { Global } \\
\text { Adaptation } \\
\text { Initiative }\end{array}$ & $\begin{array}{l}\text { The ND-GAIN Social Readiness index is based on four indicators. The social inequality } \\
\text { measure is the poorest quintile's share in national income or consumption. The indicator } \\
\text { for information and communications technology is made up of percent of individuals: us- } \\
\text { ing the Internet, with mobile phone subscriptions, with fixed phone subscriptions and with } \\
\text { fixed broadband subscriptions. Education is measured by enrollment in tertiary education } \\
\text { as a percentage of gross. Innovation is estimated by patents per capita. }\end{array}$ \\
\hline CRI & Germanwatch & $\begin{array}{l}\text { The Climate Risk Index analyses to what extent countries have been affected by the im- } \\
\text { pacts of weather-related loss events (storms, floods, heatwaves etc.) We utilize the short } \\
\text { term i.e. annual index, for the period } 2006 \text { to } 2016 \text {. }\end{array}$ \\
\hline PCY & IMF WEO & Per capita income is GDP per capita at purchasing power parity in US dollars. \\
\hline DEBT & IMF WEO & Gross government debt to GDP. \\
\hline REV & $\begin{array}{l}\text { IMF FM and } \\
\text { PFMH }\end{array}$ & Government revenues to GDP. \\
\hline EXP & $\begin{array}{l}\text { IMF FM and } \\
\text { PFMH }\end{array}$ & Government expenditures to GDP. \\
\hline
\end{tabular}




\begin{tabular}{|c|c|c|}
\hline Variable & Source & Definition \\
\hline PBA & $\begin{array}{l}\text { IMF FM and } \\
\text { PFMH }\end{array}$ & Primary balance to GDP. \\
\hline CPI & $\begin{array}{l}\text { IMF FM and } \\
\text { PFMH }\end{array}$ & Change in end of period consumer price index. \\
\hline FDI & UNCTAD & Foreign Direct Investment to GDP. \\
\hline V20 & UNEP & $\begin{array}{l}\text { Statistical dummy used to identify members of the V20 group of environmentally vulner- } \\
\text { able countries. }\end{array}$ \\
\hline G7 & G7 & Statistical dummy used to identify members of the G7 group of major economies. \\
\hline IMF & IMF & $\begin{array}{l}\text { Statistical dummy used to identify IMF bonds under concessional lending programmes. } \\
\text { For example Vanuatu's public external debt is mostly concessional (17.9\% of GDP) and } \\
\text { contracted from multilateral lenders such as the IMF, EIB, WB-IDA and ADB, or via } \\
\text { bilateral agreements such as with China Ex-Im Bank. Typically the nominal interest rates } \\
\text { of these instruments are fairly low and with long maturities over } 20 \text { years. }\end{array}$ \\
\hline RFR & Bloomberg & $\begin{array}{l}\text { The risk free rate is the benchmark US } 10 \text { year Treasury yield for any given year in the } \\
\text { sample. }\end{array}$ \\
\hline
\end{tabular}


Appendix B. Matrix of correlation coefficients

Table B.10: Correlation coefficient matrix

\begin{tabular}{|c|c|c|c|c|c|c|c|c|c|c|c|}
\hline & \multicolumn{11}{|c|}{ (1) } \\
\hline & YIELD & NDS & $\mathrm{NDC}$ & NDSR & PCY & DEBT & REV & EXP & PBA & CPI & FDI \\
\hline YIELD & 1 & & & & & & & & & & \\
\hline NDS & $0.367^{* * *}$ & 1 & & & & & & & & & \\
\hline NDC & $0.664^{* * *}$ & $0.611^{* * *}$ & 1 & & & & & & & & \\
\hline NDSR & $-0.726^{* * *}$ & $-0.515^{\star * *}$ & $-0.886^{* * *}$ & 1 & & & & & & & \\
\hline PCY & $-0.698^{* * *}$ & $-0.568^{* * *}$ & $-0.835^{\star * *}$ & $0.930^{* * *}$ & 1 & & & & & & \\
\hline DEBT & $-0.608^{* * *}$ & -0.0590 & $-0.579^{* * *}$ & $0.577^{\star * *}$ & $0.582^{* * *}$ & 1 & & & & & \\
\hline REV & $-0.567^{* * *}$ & $-0.625^{* * *}$ & $-0.825^{* * *}$ & $0.794^{* * *}$ & $0.787^{* * *}$ & $0.402^{* * *}$ & 1 & & & & \\
\hline EXP & $-0.517^{* * *}$ & $-0.569^{\star * *}$ & $-0.824^{* * *}$ & $0.796^{* * *}$ & $0.788^{* * *}$ & $0.495^{\star \star *}$ & $0.954^{* * *}$ & 1 & & & \\
\hline PBA & -0.0472 & $-0.199^{* * *}$ & -0.0684 & -0.0195 & -0.0314 & $-0.208^{* * *}$ & $0.223^{* * *}$ & -0.0432 & 1 & & \\
\hline CPI & $0.299^{\star \star \star}$ & 0.00332 & $0.105^{*}$ & $-0.150^{* *}$ & $-0.169^{\star *}$ & $-0.146^{* *}$ & $-0.176^{\star * *}$ & -0.0602 & $-0.406^{\star \star *}$ & 1 & \\
\hline FDI & $0.204^{\star * \star}$ & -0.00639 & 0.0982 & $-0.183^{\star \star \star}$ & $-0.156^{\star *}$ & $-0.227^{\star * *}$ & -0.0265 & -0.0554 & 0.0943 & -0.0496 & 1 \\
\hline
\end{tabular}




\section{Appendix C. Countries included in panel ordinary least squares regression model}

\begin{tabular}{|c|c|c|c|c|c|c|}
\hline \multirow[t]{2}{*}{ Country } & \multicolumn{2}{|c|}{ Type of debt cost observation } & \multirow[t]{2}{*}{ V20 member } & \multicolumn{3}{|c|}{ Outstanding debt 2016 (V20 only), in USD billions } \\
\hline & Marketable & Multilateral & & \begin{tabular}{|l|l} 
External total \\
\end{tabular} & Public \& guaranteed & Multilateral \\
\hline Argentina & $\checkmark$ & & & & & \\
\hline Bangladesh & $\checkmark$ & & $\checkmark$ & 41.1 & 28.6 & 26.5 \\
\hline Brazil & $\checkmark$ & & & & & \\
\hline Burkina Faso & $\checkmark$ & & $\checkmark$ & 2.8 & 2.5 & 2.5 \\
\hline Canada & $\checkmark$ & & & & & \\
\hline China & $\checkmark$ & & & & & \\
\hline Colombia & $\checkmark$ & & $\checkmark$ & 120.3 & 70.9 & 6.8 \\
\hline Costa Rica & $\checkmark$ & & $\checkmark$ & 25.6 & 11.1 & 1.2 \\
\hline Dominican Republic & $\checkmark$ & & $\checkmark$ & 28.0 & 17.2 & 1.8 \\
\hline Egypt & $\checkmark$ & & & & & \\
\hline Ethiopia & & $\checkmark$ & $\checkmark$ & 23.1 & 21.8 & 15.8 \\
\hline Fiji & & $\checkmark$ & $\checkmark$ & 0.9 & 0.7 & 0.3 \\
\hline France & $\checkmark$ & & & & & \\
\hline Germany & $\checkmark$ & & & & & \\
\hline Ghana & $\checkmark$ & & $\checkmark$ & 21.4 & 17.0 & 8.7 \\
\hline Guatemala & $\checkmark$ & & $\checkmark$ & 21.2 & 8.1 & 1.3 \\
\hline Honduras & & $\checkmark$ & $\checkmark$ & 7.6 & 6.0 & 3.4 \\
\hline India & $\checkmark$ & & & & & \\
\hline Indonesia & $\checkmark$ & & & & & \\
\hline Italy & $\checkmark$ & & & & & \\
\hline Jamaica & $\checkmark$ & & & & & \\
\hline Japan & $\checkmark$ & & & & & \\
\hline Kenya & $\checkmark$ & & $\checkmark$ & 22.3 & 18.3 & 12.7 \\
\hline Lebanon & $\checkmark$ & & $\checkmark$ & 32.0 & 27.2 & 0.8 \\
\hline Malawi & & $\checkmark$ & $\checkmark$ & 1.8 & 1.5 & 1.5 \\
\hline Maldives & & $\checkmark$ & $\checkmark$ & 1.2 & 0.9 & 0.7 \\
\hline Mexico & $\checkmark$ & & & & & \\
\hline Mongolia & $\checkmark$ & & $\checkmark$ & 23.9 & 4.5 & 2.1 \\
\hline Morocco & $\checkmark$ & & $\checkmark$ & 46.3 & 30.1 & 9.0 \\
\hline Nepal & & $\checkmark$ & $\checkmark$ & 4.3 & 3.6 & 3.6 \\
\hline Nigeria & $\checkmark$ & & & & & \\
\hline Pakistan & $\checkmark$ & & & & & \\
\hline Peru & $\checkmark$ & & & & & \\
\hline Philippines & $\checkmark$ & & $\checkmark$ & 77.3 & 33.4 & 8.4 \\
\hline Papua New Guinea & & $\checkmark$ & $\checkmark$ & 19.7 & 1.9 & 1.2 \\
\hline Rwanda & $\checkmark$ & & $\checkmark$ & 2.8 & 2.4 & 1.9 \\
\hline Senegal & $\checkmark$ & & $\checkmark$ & 6.6 & 6.1 & 4.9 \\
\hline South Africa & $\checkmark$ & & & & & \\
\hline Tanzania & $\checkmark$ & & $\checkmark$ & 16.5 & 11.2 & 9.1 \\
\hline Thailand & $\checkmark$ & & & & & \\
\hline Tunisia & $\checkmark$ & & $\checkmark$ & 28.1 & 18.3 & 5.5 \\
\hline UK & $\checkmark$ & & & & & \\
\hline United States & $\checkmark$ & & & & & \\
\hline Vanuatu & & $\checkmark$ & $\checkmark$ & 0.2 & 0.1 & 0.1 \\
\hline Venezuela & $\checkmark$ & & & & & \\
\hline Vietnam & $\checkmark$ & & $\checkmark$ & 87.0 & 48.0 & 35.0 \\
\hline Total & & & & 661.9 & 391.7 & 164.8 \\
\hline
\end{tabular}

Source: Compiled with data from Bloomberg and the World Bank. Multilateral debt is typically at concessionary rates. Total external debt consists of public, publicly-guaranteed, private non-guaranteed and IMF credit 